Vol. VIII, No. 1, April 2015

P-ISSN: 1979-858X

Halaman $47-60$

\title{
PENGARUH EFEKTIFITAS SISTEM PERPAJAKAN DAN PELAYANAN FISKUS TERHADAP KEMAUAN UNTUK MEMBAYAR PAJAK DENGAN KESADARAN MEMBAYAR PAJAK SEBAGAI VARIABEL INTERVENING
}

\author{
Popi Fauziati \\ Arfin Syahri \\ Jurusan Akuntansi, Fakultas Ekonomi, Universitas Bung Hatta
}

\begin{abstract}
This research aims to know the influential factors of willing to pay tax with their awareness of paying it as intervening variable particularly in Payakumbuh City. This research used variable independent; those are perception about taxation efficacy system, tax officers service. Intervening variable was the awareness of paying the tax. While, dependent variable was willing to pay the tax. This research used primary data by using questionnaire. Respondents were all individual tax payer who became self employeed in Payakumbuh city. Method of taking sample in this research used random sampling. The data analysis using regression analysis. The results of this data processing showed that: (1) perception of the taxation efficacy system has significant influence toward the awareness of paying the tax. (2) tax financial service have significant influence toward the awareness of paying the tax (3) the awareness of paying the tax have significant influence toward tax payers' willing to pay tax.
\end{abstract}

Keywords: Willing to Pay Tax, Awareness to Pay Tax, Perception on Taxation Efficacy System, Tax Officers Service

ABSTRAK: Penelitian ini bertujuan untuk mengetahui faktor-faktor berpengaruh dari bersedia membayar pajak dengan kesadaran mereka membayar sebagai intervensi variabel khususnya di Kota Payakumbuh. Penelitian ini menggunakan variabel independen; mereka adalah persepsi tentang perpajakan kemanjuran sistem, layanan petugas pajak. Intervensi variabel adalah kesadaran membayar pajak. Sementara, variabel dependen adalah bersedia untuk membayar pajak. Penelitian ini menggunakan data primer dengan menggunakan kuesioner. Responden semua pembayar pajak individu yang menjadi diri employeed Kota Payakumbuh. Metode pengambilan sampel dalam penelitian ini digunakan contoh acak. Analisis data menggunakan regresi. Hasil pengolahan data ini menunjukkan bahwa: (1) persepsi efektivitas sistem perpajakan memiliki pengaruh signifikan terhadap kesadaran membayar pajak. (2) pajak Jasa keuangan memiliki pengaruh yang signifikan terhadap kesadaran membayar pajak (3) kesadaran membayar pajak memiliki pengaruh yang signifikan terhadap wajib pajak bersedia membayar pajak.

Kata kunci: Kemauan Membayar Pajak, Kesadaran untuk Membayar Pajak, Persepsi Efektivitas Sistem Perpajakan, Layanan Petugas Pajak.

\footnotetext{
${ }^{1}$ Draft pertama: 12 Januari 2015; Revisi: 27 Januari 2015; Diterima: 19 Februari 2015

Penulis dapat dikontak melalui: popifauziati@bunghatta.ac.id
} 


\section{PENDAHULUAN}

Pemerintah Indonesia secara terus menerus berusaha meningkatkan sumber pembiayaan pembangunan internal, salah satu sumber pembiayaan pembangunan internal adalah pajak. besarnya peran pajak dalam membiayai pembangunan juga tercermin dari sumber penerimaan Anggaran Pendapatan dan Belanja Negara (APBN) tahun 2013 yang mencapai $78 \%$. Mengingat pentingnya peranan pajak, maka pemerintah dalam hal ini Direktorat Jenderal Pajak telah melakukan berbagai upaya untuk memaksimalkan penerimaan pajak. Salah satu upaya yang dilakukan adalah melalui reformasi peraturan perundang-undangan di bidang perpajakan dengan diberlakukannya self assessment system.

Salah satu penerimaan pajak yang sangat potensial yang dipungut pemerintah secara langsung adalah pajak penghasilan yaitu beban pajak tersebut menjadi tanggung jawab wajib pajak yang bersangkutan dalam arti tidak dapat dilimpahkan kepada pihak lain. Secara umum semua orang memiliki potensi sebagai penerima penghasilan, entah masih anak-anak, bahkan bayi dan balita, remaja, dewasa dan orang-orang yang sudah tua, termasuk yang lanjut usia sekalipun (Judisseno, 2005).Pajak Penghasilan (PPh) adalah salah satu sumber peneriman negara yang berasal dari pendapatan rakyat yang merupakan wujud kewajiban dan peran serta rakyat dalam pembiayaan dan pembangunan nasional (Purwono, 2010).

Salah satu penyumbang pajak untuk negara Indonesia berasal dari Sumatera Barat. Berikut dapat dilihat Rencana dan Realisasi Penerimaan Pajak Kanwil DJP Sumatera Barat dan Jambi Tahun 2011-2012 dimana persentase pencapaian pajak pada Kanwil DJP Sumatera Barat dan Jambi pada tahun 2012 mengalami penurunan untuk rencana sebesar 3,16\% sedangkan realisasi mengalami peningkatan sebesar 5,59\%. Begitu juga dengan persentase pencapaian pajak pada KPP Pratama Payakumbuh pada tahun 2012 juga mengalami penurunan untuk rencana sebesar $17,73 \%$. Sedangkan realisasi juga mengalami penurunan sebesar $14,78 \%$

Sementara jika dilihat dari kontribusi pajak KPP Pratama Payakumbuh terhadap kanwil DJP Sumatera Barat dan Jambi mengalami fluktuasi baik dari rencana maupun realisasi per jenis pajak. Hasil selengkapnya tentang kontribusi rencana dan realisasi penerimaan pajak KPP Pratama Bukittinggi terhadap Kanwil DJP Sumatera Barat dan Jambi dapat dilihat rencana kontribusi pajak pengasilan kota Payakumbuh pada tahun 2011 sebesar 2,96\% naik pada tahun 2012 menjadi 3,37\%, sementara untuk realisasi kontribusi pajak penghasilan kota Payakumbuh pada tahun 2011 sebesar 3,24\% turun pada tahun 2012 menjadi $7,67 \%$. Hal ini berbanding terbalik dengan rencana kontribusi pajak PPN dan PpnBM kota Payakumbuh pada tahun 2011 sebesar 2,46\% turun pada tahun 2012 menjadi 1,48\%, sementara untuk realisasi kontribusi pajak PPN dan PpnBM kota Payakumbuh pada tahun 2011 sebesar 1,71\%, mengalami peningkatan pada tahun 2012 menjadi 2,14\%.

Kemudian jika dilihat dari rencana kontribusi pajak PBB dan BPHTB kota Payakumbuh pada tahun 2011 sebesar 4,16\% turun pada tahun 2012 menjadi 1,11\%, diikuti juga penurunan realisasi kontribusi pajak pada tahun 2011 sebesar 5,87\% menjadi 1,19\% pada tahun 2012. Sedangkan jika dilihat untuk rencana kontribusi pajak lainnya dan PIB kota Payakumbuh pada tahun 2011 sebesar 1,83\% naik pada tahun 2012 menjadi 4,50\%, sementara untuk realisasi kontribusi pajak lainnya dan PIB kota Payakumbuh pada tahun 2011 sebesar 4,37\% naik pada tahun 2012 menjadi 4,98\%.

Berdasarkan data diatas dapat disimpulkan bahwa seharusnya pajak penghasilan bisa memberikan kontribusi yang lebih banyak dibandingkan jenis pajak lainnya. Namun pajak penghasilan baik rencana maupun realisasi keduanya sama-sama mengalami penurunan. Penurunan ini diprediksi akibat berkurangnya kesadaran untuk membayar pajak. Nugroho dan Zulaikha, (2012) mengatakan faktor-faktor yang mempengaruhi berkurangnya kesadaran membayar pajak antara lain kurangnya pengetahuan dan 
pemahaman yang dimiliki oleh wajib pajak, persepsi atas efektivitas sistem perpajakan yang buruk, kemudian pelayanan fiskus yang buruk, sehingga dengan berkurangnya kesadaran membayar pajak juga berpengaruh kepada kemauan untuk membayar pajak.

Pada penelitian ini akan diteliti tentang faktor-faktor yang mempengaruhi kemauan untuk membayar pajak wajib pajak orang pribadi yang melakukan pekerjaan bebas. Penelitian ini merupakan replikasi dari penelitian Nugroho dan Zulaikha, (2012). Selanjutnya yang mempengaruhi kesadaran membayar pajak adalah adanya pelayanan fiskus yang berkualitas. Munculnya oknum seperti Gayus, Dhana Widyatmika dan banyak petugas pajak lainnya membuat keyakinan wajib pajak atas kinerja pelayan fiskus berkurang sehingga wajib pajak tidak mau membayar pajak karena takut uangnya digelapkan, bukan untuk pembangunan negara, atau adanya biaya tambahan yang dipungut oleh fiskus.

\section{Rumusan Masalah}

Berdasarkan latar belakang penelitian diatas, maka dapat ditarik permasalahanpermasalahan yang timbul dalam penelitian ini. Adapun pertanyaan yang timbul adalah sebagai berikut :

1. Apakah persepsi atas efektifitas sistem perpajakan berpengaruh terhadap kesadaran membayar pajak?

2. Apakah pelayanan fiskus yang berkualitas berpengaruh terhadap kesadaran membayar pajak?

3. Apakah kesadaraan membayar pajak berpengaruh terhadap kemauan membayar pajak?

\section{KERANGKA TEORI DAN PENGEMBANGAN HIPOTESIS \\ Persepsi atas efektifitas sistem perpajakan}

Persepsi dapat dinyatakan sebagai suatu proses pengorganisasian, penginteprestasian terhadap stimulus oleh organisasi atau individu sehingga merupakan suatu yang berarti dan merupakan aktifitas integrated dalam diri individu. Sedangkan efektifitas memiliki pengertian suatu pengukuran yang menyatakan seberapa jauh target (kualitas, kuantitas, dan waktu) telah tercapai. Persepsi wajib pajak terhadap kinerja penerimaan pajak. Suryadi (2006) menyatakan bahwa persepsi masyarakat terhadap kinerja Badan Perpajakan Nasional Swedia, ini dilihat dari: kesadaran prosedur yang bermanfaat bagi wajib pajak, kebutuhan bagi wajib pajak, perlakuan yang adil, keahlian aparat dalam mendeteksi kesalahan,serta dalam mengoreksi laporan pajak. Hasil penelitian menyimpulkan bahwa persepsi wajib pajak yang positif dapat mempengaruhi perilaku wajib pajak dalam membayar pajak.

Widayati dan Nurlis (2010) hal-hal yang mengindikasikan efektifitas sistem perpajakan yang saat ini dapat dirasakan oleh wajib pajak antara lain :

(1) Adanya sistem pelaporan melalui $e-S P T$ dan $e$-filling. Wajib pajak dapat melaporkan pajak secara lebih mudah dan cepat.

(2) Pembayaran melalui e-banking yang memudahkan Wajib Pajak dapat melakukan pembayaran dimana saja dan kapan saja.

(3) Penyampaian SPT melalui drop box yang dapat dilakukan di berbagai tempat, tidak harus di KPP tempat Wajib Pajak terdaftar.

(4) Peraturan perpajakan dapat diakses secara lebih cepat melalui internet, tanpa harus menunggu adanya pemberitahuan dari KPP tempat Wajib Pajak terdatar.

(5) Pendaftaran NPWP yang dapat dilakukan secara online melalui eregistration dari website pajak. Hal ini akan memudahkan Wajib Pajak untuk memperoleh NPWP secara lebih cepat.

Persepsi wajib pajak terhadap sistem perpajakan di Indonesia berkaitan dengan media yang digunakan dalam membayar pajak. Jika wajib pajak merasa bahwa sistem 
parpajakan yang ada adalah terpercaya, handal dan akurat, maka wajib pajak akan memiliki pandangan yang positif untuk sadar membayar pajak. Namun jika sistem perpajakan yang ada tidak memuaskan bagi wajib pajak, maka hal itu dapat turut mempengaruhi kesadaran wajib pajak.

Berdasarkan hal tersebut maka hipotesis yang dapat dirumuskan adalah:

H1: Persepsi atas efektifitas sistem perpajakan berpengaruh terhadap kesadaran membayar pajak

\section{Pengaruh pelayanan fiskus yang berkualitas terhadap kesadaran membayar pajak}

Pelayanan yang baik merupakan salah satu faktor penting dalam menciptakan kepuasan kepada pelanggan. Suatu layanan dapat dikatakan baik apabila usaha yang dijalankan sesuai dengan apa yang diharapkan. Pelayanan yang berkualitas adalah pelayanan yang dapat memberikan kepuasan kepada pelanggan dan tetap dalam batas memenuhi standar pelayanan yang dapat dipertanggungjawabkan serta harus dilakukan secara terus-menerus. Pelayanan yang diberikan oleh fiskus selama proses perpajakan berkaitan dengan sikap Wajib Pajak. Proses perpajakan melibatkan fiskus dan Wajib Pajak membuat pelayanan yang diberikan oleh fiskus turut membentuk sikap (atitude)Wajib Pajak dalam mengikuti proses perpajakan. Semakin baik pelayanan fiskus maka Wajib Pajak akan memilkik sikap yang positif terhadap proses perpajakan. Namun jika pelayanan fiskus tidak baik, hal itu akan membuat Wajib Pajak enggan untuk membayar pajak sesuai ketentuan yang berlaku.

Nugroho dan Zulaikha, (2012) menyimpulkan bahwa pengetahuan dan pemahaman akan pertaturan perpajakan, pelayanan fiskus yang berkulaitas, dan persepi atas efektifitas sistem perpajakan berpengaruh postif terhadap kesadaran membayar pajak, kemudian variabel kesadaran membayar pajak berpengaruh positif terhadap kemauan membayar pajak. Suryadi (2006) menekankan pada pentingnya kualitas aparat pajak dalam memberikan pelayan kepada Wajib Pajak.

Berdasarkan hal tersebut maka hipotesis yang dapat dirumuskan adalah:

H2: Pelayanan fiskus yang berkualitas berpengaruh terhadap kesadaran membayar pajak

\section{Pengaruh kesadaran membayar pajak dengan kemauan membayar pajak}

Kesadaran membayar pajak memiliki arti keadaan dimana seseorang mengetahui, memahami, dan mengerti tentang cara membayar pajak. Nugroho dan Zulaikha, (2012) menyimpulkan dari data yang dianalisis, hasil uji yang di lakukan diperoleh kesimpulan bahwa pengetahuan dan pemahaman akan pertaturan perpajakan, pelayanan fiskus yang berkulaitas, dan persepi atas efektifitas sistem perpajakan berpengaruh postif terhadap kesadaran membayar pajak, kemudian variabel kesadaran membayar pajak berpengaruh positif terhadap kemauan membayar pajak.

Penelitian Chatarina (2004) menyimpulkan bahwa sikap aparat pajak tidak mempengaruhi kesadaran wajib pajak dalam membayar pajak, namun sikap aparat pajak bersama-sama dengan pembelajaran pajak dan sosialisasi perpajakan secara signifikan mempengaruhi kesadaran wajib pajak dalam membayar pajak.

Permadi, Nasir dan Yuneita (2013) studi kemauan membayar pajak pada wajib pajak orang pribadi yang melakukan pekerjaan bebas (Kasus Pada KPP Pratama Tampan Pekanbaru) .Berdasarkan hasil penelitian, maka dapat disimpulkan: (1) Variabel kesadaran membayar pajak, pengetahuan dan pemahaman tentang peraturan pajak serta norma moral secara parsial berpengaruh terhadap kemauan membayar pajak pada wajib pajak orang pribadi yang melakukan pekerjaan bebas. (2) Variabel persepsi yang baik atas efektifitas sistem perpajakan serta variabel tingkat kepercayaan terhadap sistem pemerintahan dan hukum secara parsial tidak berpengaruh terhadap kemuan membayar pajak pada wajib pajak orang pribadi yang melakukan pekerjaan bebas. 
Berdasarkan hal tersebut maka hipotesis yang dapat dirumuskan adalah:

H3: Kesadaran membayar pajak berpengaruh terhadap kemauan membayar pajak

\section{Kerangka Pemikiran}

Metode penelitian menggunakan dua persamaan. Pada persamaan pertama pengetahuan dan pemahaman akan perarturan perpajakan, pelayanan fiskus yang berkualitas terhadap kesadaran membayar pajak. Kemudian pada persamaan kedua kesadaran membayar pajak terhadap kemauan membayar pajak. Pada bagian ini akan ditampilkan ringkasan gambar kerangka pemikiran yang akan ditunjukan pada gambar 1 berikut ini :

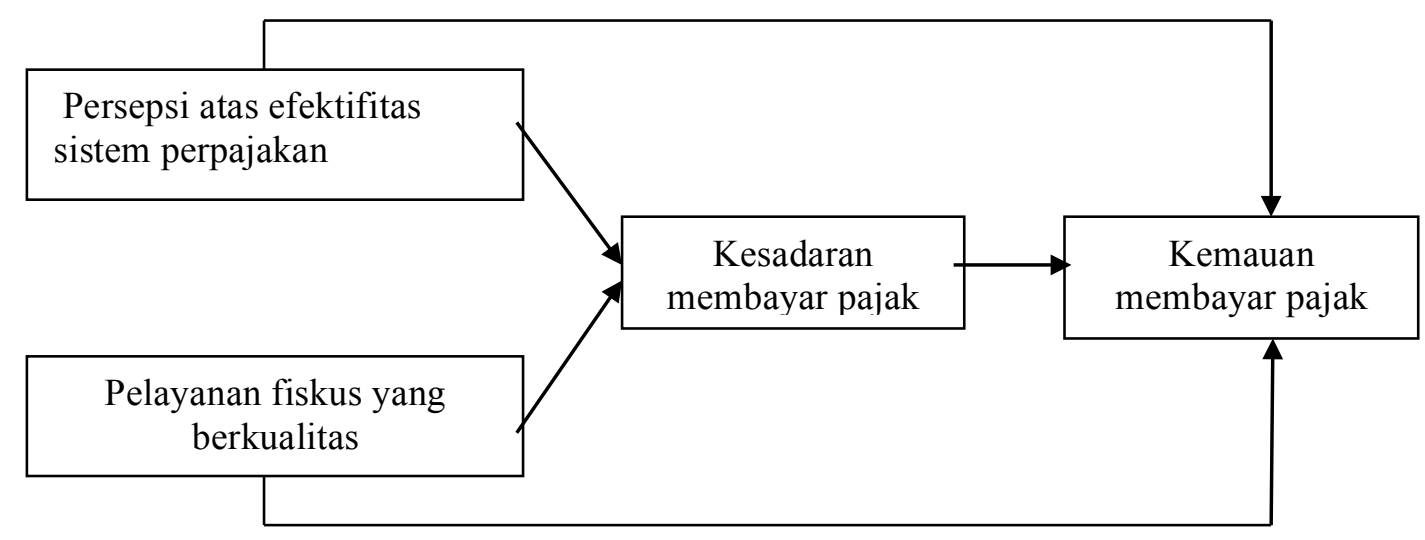

Gambar 1. Kerangka Pemikiran

\section{METODA PENELITIAN}

Populasi dan Sampel

Populasi dalam penelitian ini adalah seluruh wajib pajak orang pribadi (WPOP) yang terdaftar di KPP Pratama Payakumbuh yang berjumlah 22.368 orang per 20 Maret 2014. Kemudian sampel dalam penelitian ini adalah wajib pajak orang pribadi (WPOP) yang melakukan pekerjaan bebas yang terdaftar di KPP Pratama Payakumbuh.

Berdasarkan pada rumus slovin, maka perhitungan untuk jumlah sampel yang akan digunakan dalam penelitian ini adalah sebagai berikut :

$$
\begin{aligned}
& n=\frac{N}{1+N(e)^{2}} \\
& n=\frac{22.368}{1+22.368(0,1)^{2}}
\end{aligned}
$$

Maka jumlah sampel yang digunakan dalam penelitian ini adalah sebanyak 100 responden. Teknik pemilihan sampel yang digunakan adalah random sampling, yaitu cara pengambilan sampel yang memberikan kesempatan yang sama untuk diambil kepada setiap elemen populasi.

\section{Teknik Pengumpulan Data}

Metode pengumpulan data yang digunakan dalam penelitian ini adalah menggunakan kuesioner. Sugiyono (2003) mengatakan kuesioner merupakan teknik pengumpulan data yang dilakukan dengan cara memberi seperangkat pertanyaan atau pernyataan tertulis kepada responden untuk dijawabnya. 


\section{Definisi Operasional Variabel dan Pengukuran Variabel}

Persepsi atas efektifitas sistem perpajakan

Persepsi adalah proses kognitif yang dialami setiap orang dalam memahami informasi tentang lingkungannya melalui pancaindera. Sedangkan efektifitas memiliki pengertian suatu pengukuran yang menyatakan seberapa jauh target (kualitas,kuantitas dan waktu) telah tercapai. variabel diukur dengan instrumen yang terdiri dari lima pertanyaan, yang diadopsi dari penelitian Widayati dan Nurlis, (2010) berupa:

a. Pembayaran pajak melalui e-Banking

b. Penyampaian SPT melalui e-SPT dan e-Filling

c. Penyampaian SPT melalui drop box

d. Update peraturan pajak terbaru secara online melalui internet.

e. Pendaftaran NPWP melalui e-register

Variabel ini diukur dengan menggunakan skala likert yaitu skala yang didesain untuk menelaah seberapa kuat subjek setuju (sering) atau tidak setuju (tidak sering) dengan pernyataan pada skala 4 atau interval 1 sampai 4 . Interval 1 sampai 4 tersebut terdiri dari $; 1=$ sangat tidak setuju, 2 = tidak setuju, $3=$ setuju, $4=$ sangat setuju .

\section{Pelayanan Fiskus}

Pelayanan yang berkulitas terhadap wajib pajak adalah usaha yang dilakukan oleh kantor pelayanan pajak untuk melayani wajib pajak secara maksimal agar wajib pajak tidak mengalami kebingungan saat membayar pajak. Variabel diukur dengan instrumen yang terdiri dari lima item pertanyaan, yang diadopsi dari penelitian Yulianawati (2011) berupa :

a. Fiskus diharapkan memiliki kompetensi Skill, Knowledge, Experience dalam hal kebijakan perpajakan, administrasi pajak, dan perundang-undangan.

b. Fiskus memiliki motivasi tinggi sebagai pelayan publik.

c. Perluasan Tempat Pelayanan Terpadu (TPT).

d. TPT dapat memudahkan pengawasan terhadap proses pelayanan yang diberikan kepada wajib pajak.

e. Sistem informasi perpajakan dan sistem administrasi perpajakan merupakan sistem layanan prima kepada wajib pajak menjadi semakin nyata.

Variabel ini diukur dengan menggunakan skala likert yaitu skala yang didesain untuk menelaah seberapa kuat subjek setuju (sering) atau tidak setuju (tidak sering) dengan pernyataan pada skala 4 atau interval 1 sampai 4 (Sekaran, 2006). Interval 1 sampai 4 tersebut terdiri dari $; 1=$ sangat tidak setuju, $2=$ tidak setuju, $3=$ setuju, $4=$ sangat setuju.

Kesadaran membayar pajak

Kesadaran membayar pajak memiliki arti keadaan dimana seseorang mengetahui, memahami, dan mengerti tentang cara membayar pajak. Variabel diukur dengan instrumen yang terdiri dari empat item pertanyaan, yang diadopsi dari penelitian Widayati dan Nurlis, (2010) berupa :

a. Pajak merupakan bentuk partisipasi dalam menunjang pembangunan negara

b. Penundaan pembayaran pajak dan pengurangan beban pajak sangat merugikan negara

c. Pajak ditetapkan dengan undang-undang dan dapat dipaksakan

d. Membayar pajak tidak sesuai dengan yang seharusnya dibayar akan merugikan negara.

Variabel ini diukur dengan menggunakan skala likert yaitu skala yang didesain untuk menelaah seberapa kuat subjek setuju (sering) atau tidak setuju (tidak sering) dengan pernyataan pada skala 4 atau interval 1 sampai 4 . Interval 1 sampai 4 tersebut terdiri dari $; 1=$ sangat tidak setuju, $2=$ tidak setuju, $3=$ setuju, $4=$ sangat setuju . 
Kemauan Membayar Pajak

Variabel dependen atau terikat adalah variabel yang dijelaskan atau dipengaruhi oleh variabel bebas. Dalam penelitian ini variabel terikatnya adalah kemauan membayar pajak.

Kemauan membayar pajak dapat diartikan sebagai suatu nilai yang rela dikontribusikan oleh seseorang (yang ditetapkan dengan peraturan) yang digunakan untuk membiayai pengeluaran umum Negara dengan tidak mendapat kontraprestasi secara langsung (Vanessa dan Hari, 2009). Variabel diukur dengan instrumen yang terdiri dari lima item pertanyaan, yang diadopsi dari penelitian Widayati dan Nurlis, (2010) berupa :
a. Konsultasi sebelum melakukan pembayaran pajak
b. Dokumen yang diperlukan dalam membayar pajak
c. Informasi mengenai cara dan tempat pembayaran pajak
d. Informasi mengenai batas waktu pembayaran pajak
e. Membuat alokasi dana untuk membayar pajak

Variabel ini diukur dengan menggunakan skala likert yaitu skala yang didesain untuk menelaah seberapa kuat subjek setuju (sering) atau tidak setuju (tidak sering) dengan pernyataan pada skala 4 atau interval 1 sampai 4 . Interval 1 sampai 4 tersebut terdiri dari; 1 = sangat tidak setuju, 2 = tidak setuju, 3 = setuju, 4 = sangat setuju .

\section{Metode Analisa Data}

Dalam melakukan pengujian statistik, maka penulis melakukan pengujian data yang digunakan dalam penelitian ini dengan menggunakan tahapan pengujian meliputi:

\section{Uji Kualitas Data}

a. Uji Validitas

Ghozali, (2013) mengatakan uji ini dapat dilihat dari nilai Kaiser Meyer Olkin Measure Of Sampling Adequency (KMO - MSA) dari variabel jika berada diatas 0,5 hal ini memberikan arti bahwa item-item dari variabel tersebut valid untuk di uji (Ghozali, 2013). Sebaliknya jika factor loading kurang dari o,4 berarti item tersebut tidak valid.

b. Uji Reliabilitas

Sekaran (2011) ) mengatakan bahwa alfa cronbach untuk pengukuran adalah o,82. Semakin dekat koefisien keandalan dengan 1,o semakin baik. Secara umum, keandalan kurang dari o,6o dianggap buruk, keandalan dalam kisaran o,7o bisa diterima, dan lebih dari o,8o adalah baik. Dengan demikian, keandalan konsistensi internal (internal consistensy) pengukuran yang digunakan dalam studi ini dapat dianggap baik.

\section{Uji Normalitas}

Untuk mengetahui pola distribusi dari variabel yang digunakan dalam penelitian ini maka digunakan bantuan uji non parametrik One Sample Kolmogorov Smirnov Test. Normalnya sebuah item ditentukan dari nilai asymp sig (2 tailed) yang dihasilkan dalam pengujian yang harus $>$ alpha 0,05 (Ghozali, 2013).

\section{Analisa Regresi Linear Sederhana}

Didalam analisis regresi, selain mengukur kekuatan hubungan antara dua variabel atau lebih yang menunjukkan arah hubungan antara variabel dependen dengan variabel independen. Analisis yang digunakan dalam penilitian ini adalah analisa regresi linear sederhana dengan melihat pengaruh hubungan persepsi atas efektifitas sistem perpajakan dan pelayanan fiskus yang berkualitas terhadap kesadaran membayar pajak, dan kesadaran membayar pajak terhadap kemauan membayar pajak (Ghozali, 2013). 


\section{HASIL DAN PEMBAHASAN}

\section{Karakteristik Responden}

Berdasarkan proses pentabulasian data yang telah dilakukan dapat diklasifikasikan responden yang berpartisipasi di dalam penelitian terbanyak berjenis kelamin pria yaitu sebanyak 43 orang $(64,2 \%)$, berusia $25-35$ tahun sebanyak 26 orang $(38,3 \%)$ dengan bidang usaha perdagangan sebanyak 34 orang $(50,7 \%)$ serta pendapatan/tahun, yaitu berkisar 100250 Juta sebanyak 44 orang $(65,7 \%)$.

\section{Uji Validitas dan Reliabilitas Uji Validitas}

Hasil uji validitas tersebut dapat dilihat pada tabel berikut :

Tabel 1. Hasil Pengujian Validitas Data

\begin{tabular}{|lccc|}
\hline \multicolumn{1}{|c}{ Variabel } & KMO & $\begin{array}{c}\text { Faktor } \\
\text { Loading }\end{array}$ & Keterangan \\
\hline $\begin{array}{l}\text { persepsi atas efektifitas sistem } \\
\text { perpajakan (x1) }\end{array}$ & 0,619 & $0,444-0,872$ & Valid \\
pelayanan fiskus (x2) & 0,519 & $0,572-0,952$ & Valid \\
kesadaran membayar pajak (z) & 0,599 & $0,659-0,911$ & Valid \\
kemauan membayar pajak (y) & 0,729 & $0,598-0,770$ & Valid \\
\hline
\end{tabular}

Sumber : data primer diolah, 2015

Pada tabel 1 terlihat bahwa seluruh variabel yang digunakan item pertanyaannya semuanya memiliki factor loading > o,40 dan nilai Kaiser Meyer Olkin Measure Of Sampling Adequency (KMO - MSA) seluruh variabel $>0,5$, oleh sebab itu seluruh variabel tersebut yang terdiri dari persepsi atas efektifitas sistem perpajakan, pelayanan fiskus, kesadaran membayar pajak, dan kemauan membayar pajak memiliki item pertanyaan yang dinyatakan valid dan dapat terus digunakan dalam pengujian reliabilitas.

Pengujian Reliabilitas Data

Berikut ini disajikan ringkasan hasil uji reliabilitas untuk setiap variabel :

Tabel 2. Hasil Pengujian Reliabilitas Data

\begin{tabular}{|llcc|}
\hline No & \multicolumn{1}{c}{ Variabel } & Cronbach Alpha & Keterangan \\
\hline 1. & Persepsi atas efektifitas sistem & 0,618 & Reliabel \\
& perpajakan (x1) & 0,605 & Reliabel \\
2. & pelayanan fiskus (x2) & 0,604 & Reliabel \\
3. & kesadaran membayar pajak (z) & 0,762 & Reliabel \\
4 & kemauan membayar pajak (y) & & \\
\hline
\end{tabular}

Sumber : data primer diolah, 2015

Berdasarkan tabel 2 rangkuman hasil uji reliabilitas diatas, nilai cronbach alpha untuk seluruh variabel yang digunakan adalah besar dari o.6o dan ini menunjukkan seluruh item pernyataan dinyatakan reliabel atau handal

\section{Uji Asumsi Klasik}

Uji Normalitas

Berdasarkan hasil pengujian normalitas data dengan menggunakan uji Kolmogrov Smirnov ditemukan hasil sebagai berikut : 
Tabel 3. Hasil Pengujian Normalitas One-Sample Kolmogorov-Smirnov Test

\begin{tabular}{|lccc|}
\hline \multicolumn{1}{|c}{ Variabel } & $\begin{array}{c}\text { Asymp. Sig. } \\
(2 \text {-tailed })\end{array}$ & $\begin{array}{c}\text { Cut } \\
\text { Off }\end{array}$ & Keterangan \\
\hline persepsi atas efektifitas sistem perpajakan (x1) & 0,395 & 0,05 & Normal \\
pelayanan fiskus (x2) & 0,220 & 0,05 & Normal \\
kesadaran membayar pajak (z) & 0,098 & 0,05 & Normal \\
kemauan membayar pajak (y) & 0,401 & o,05 & Normal \\
\hline
\end{tabular}

Sumber : data primer diolah, 2015

Dengan pengujian One Sample Kolmogorov Smirnov Test dapat diketahui bahwa data kuesioner yang penulis kumpulkan berdistribusi normal. Hasil ini dapat dilihat dari nilai Asymp. Sig. (2-tailed) seluruh variabel besar dari o,05, ini menunjukkan bahwa secara umum data yang ditemukan sudah memenuhi asumsi kenormalan data sehingga pengujian statistik parametrik dapat dilakukan untuk membuktikan kebenaran hipotesis yang telah diajukan dalam penelitian ini.

\section{Pengujian Hipotesis}

Pengaruh Persepsi Atas Efektifitas Sistem Perpajakan Terhadap Kesadaran Membayar Pajak

\section{Uji Koefisien Determinasi (R Square)}

Koefisien determinasi pada intinya mengukur seberapa jauh kemampuan model dalam menerangkan variasi variabel dependen (Ghozali, 2013). Selanjutnya dari hasil pengolahan data (data primer) yang dapat dilihat pada tabel 4 diperoleh hasil penelitian bahwa :

\section{Tabel 4. Hasil Pengujian Untuk Uji Koefisien Determinasi (R Square) Persamaan I}

\begin{tabular}{|c|c|c|c|c|}
\hline Model & $\mathrm{R}$ & $\begin{array}{c}\mathrm{R} \\
\text { Square }\end{array}$ & Adjusted R Square & Std. Error of the Estimate \\
\hline 1 & $0,311^{a}$ & 0,096 & 0,083 & 1,60638 \\
\hline
\end{tabular}

Sumber : data primer diolah, 2015

Dari hasil pengolahan data (data Primer) yang dapat dilihat pada tabel 4 diperoleh hasil bahwa $R$ square adalah sebesar 0.096 hal ini berarti 9,6\% dari kesadaran membayar pajak yang dapat dijelaskan oleh persepsi atas efektifitas sistem perpajakan sedangkan sisanya sebesar 90,4\% dijelaskan oleh faktor-faktor lain yang tidak diteliti dalam penelitian ini.

\section{Pengujian Uji Parsial \& t-test dan Pembahasan Hipotesis Pertama}

Untuk membuktikan pengaruh variabel independen terhadap variabel dependen secara parsial atau individu.

Tabel 5

Hasil Pegujian Hipotesis Untuk Uji Parsial Dengan t- test Persamaan I

\begin{tabular}{|l|c|c|c|}
\hline \multicolumn{1}{|c|}{ Variabel } & Koefisien regresi & Sig & Alpha \\
\hline Konstanta & 8,773 & & \\
\hline $\begin{array}{l}\text { Persepsi atas efektifitas sistem } \\
\text { perpajakan (x1) }\end{array}$ & $\mathbf{0 , 2 2 1}$ & $\mathbf{0 , 0 1 1}$ & $\mathbf{0 , 0 5}$ \\
\hline
\end{tabular}

Sumber : data primer diolah, 2015 
Hipotesis pertama bertujuan untuk melihat pengaruh persepsi atas efektifitas sistem perpajakan terhadap kesadaran membayar pajak. Berdasarkan tabel 5 diatas dapat dilihat bahwa nilai signifikannya o,011 < alpha o,05 sehingga dapat disimpulkan bahwa persepsi atas efektifitas sistem perpajakan berpengaruh terhadap kesadaran membayar pajak, berarti $\mathrm{H}_{1}$ diterima pada penelitian ini. Persepsi dapat dinyatakan sebagai suatu proses pengorganisasian, penginteprestasian terhadap stimulus oleh organisasi atau individu sehingga merupakan suatu yang berarti dan merupakan aktifitas integrated dalam diri individu. Sedangkan efektifitas memiliki pengertian suatu pengukuran yang menyatakan seberapa jauh target (kualitas, kuantitas, dan waktu) telah tercapai. Persepsi wajib pajak terhadap kinerja penerimaan pajak, Maria Karanta, et.al

Hasil penelitian ini konsisten dengan hasil penelitian Nugroho dan Zulaikha (2012), dimana berdasarkan hasil uji yang dilakukan diperoleh bahwa persepsi atas efektifitas sistem perpajakan berpengaruh postif terhadap kesadaran membayar pajak.

\section{Pengaruh Pelayanan Fiskus Yang Berkualitas Terhadap Kesadaran Membayar Pajak Uji Koefisien Determinasi (R Square)}

Koefisien determinasi pada intinya mengukur seberapa jauh kemampuan model dalam menerangkan variasi variabel dependen (Ghozali, 2013). Selanjutnya dari hasil pengolahan data (data primer) yang dapat dilihat pada tabel 6 diperoleh hasil penelitian bahwa :

Tabel 6

Hasil Pengujian Untuk Uji Koefisien Determinasi (R Square) Persamaan II

\begin{tabular}{|l|c|r|r|r|}
\hline Model & \multicolumn{1}{|c|}{ R } & R Square & Adjusted R Square & Std. Error of the Estimate \\
\hline 1 & $0,589^{\mathrm{a}}$ & 0,347 & 0,337 & 1,36559 \\
\hline
\end{tabular}

Sumber : data primer diolah, 2015

Dari hasil pengolahan data (data Primer) yang dapat dilihat pada tabel 4.12 diperoleh hasil bahwa $R$ square adalah sebesar 0.347 hal ini berarti 34,7\% dari kesadaran membayar pajak yang dapat dijelaskan oleh pelayanan fiskus sedangkan sisanya sebesar $65,3 \%$ dijelaskan oleh faktor-faktor lain yang tidak diteliti dalam penelitian ini.

\section{Pengujian Hipotesis Kedua}

Untuk membuktikan pengaruh variabel independen terhadap variabel dependen secara parsial atau individu.

Tabel 7

Hasil Pegujian Hipotesis Untuk Uji Parsial Dengan t- test Persamaan II

\begin{tabular}{|l|c|c|c|}
\hline \multicolumn{1}{|c|}{ Variabel } & Koefisien regresi & Sig & Alpha \\
\hline Konstanta & 3,982 & & \\
\hline Pelayanan fiskus yang berkualitas (x2) & 0,536 & 0,000 & 0,05 \\
\hline
\end{tabular}

Sumber : data primer diolah, 2015

Hipotesis kedua bertujuan untuk melihat pengaruh pelayanan fiskus terhadap kesadaran membayar pajak. Berdasarkan tabel 7 diatas dapat dilihat bahwa nilai signifikannya $0,000<$ alpha 0,05 sehingga dapat disimpulkan bahwa pelayanan fiskus berpengaruh terhadap kesadaran membayar pajak, berarti $\mathrm{H}_{2}$ diterima pada penelitian ini.

Pelayanan yang berkualitas merupakan salah satu faktor penting dalam menciptakan kepuasan kepada pelanggan. Suatu layanan dapat dikatakan baik apabila usaha yang dijalankan sesuai dengan apa yang diharapkan. Pelayanan yang berkualitas 
adalah pelayanan yang dapat memberikan kepuasan kepada pelanggan dan tetap dalam batas memenuhi standar pelayanan yang dapat dipertanggungjawabkan serta harus dilakukan secara terus-menerus (Supadmi, 2009).

Kepuasan wajib pajak dalam mendapatkan pelayanan fiskus diduga akan berpengaruh terhadap kepatuhan wajib pajak di dalam membayar pajak. Suryadi (2006) menekankan pada pentingnya kualitas aparat pajak dalam memberikan pelayanan kepada wajib pajak. Ada beberapa indikator bahwa pelayanan fiskus yang berkualitas dapat mempengaruhi kemauan untuk membayar pajak. Pertama, fiskus diharapkan memiliki kompetensi dalam arti memiliki keahlian, pengetahuan dan pengalaman dalam hal perpajakan, administrasi pajak dan perundang-undangan perpajakan. Kedua, fiskus harus memiliki motivasi yang tinggi sebagai pelayan publik. Ketiga, Kantor Pelayanan Pajak (KPP) diharapkan perluasan tempat pelayanan terpadu (TPT). Hasil penelitian ini konsisten dengan hasil penelitian Nugroho dan Zulaikha (2012), dimana berdasarkan hasil uji yang dilakukan menunjukkan pelayanan fiskus yang berkualitas berpengaruh positif terhadap kesadaran membayar pajak.

\section{Pengaruh Kesadaran Membayar Pajak Terhadap Kemauan Membayar Pajak Uji Koefisien Determinasi (R Square)}

Koefisien determinasi pada intinya mengukur seberapa jauh kemampuan model dalam menerangkan variasi variabel dependen (Ghozali, 2013). Selanjutnya dari hasil pengolahan data (data primer) yang dapat dilihat pada tabel 8 diperoleh hasil penelitian bahwa:

Tabel 8

Hasil Pengujian Untuk Uji Koefisien Determinasi (R Square) Persamaan III

\begin{tabular}{|l|c|c|c|c|}
\hline Model & R & R Square & Adjusted R Square & Std. Error of the Estimate \\
\hline 1 & $0,275^{\mathrm{a}}$ & 0,076 & 0,062 & 2,29862 \\
\hline
\end{tabular}

Sumber : data primer diolah, 2015

Dari hasil pengolahan data (data Primer) yang dapat dilihat pada tabel 4.14 diperoleh hasil bahwa $R$ square adalah sebesar 0.076 hal ini berarti 7,6\% dari kemauan membayar pajak yang dapat dijelaskan oleh kesadaran membayar pajak sedangkan sisanya sebesar 92,4\% dijelaskan oleh faktor-faktor lain yang tidak diteliti dalam penelitian ini.

\section{Pengujian Uji Parsial \& t-test dan Pembahasan Hipotesis Ketiga}

Untuk membuktikan pengaruh variabel independen terhadap variabel dependen secara parsial atau individu.

\section{Tabel 9}

Hasil Pegujian Hipotesis Untuk Uji Parsial Dengan t- test Persamaan III

\begin{tabular}{|lccc|}
\hline \multicolumn{1}{|c}{ Variabel } & Koefisien regresi & Sig & Alpha \\
\hline Konstanta & 9,634 & & \\
kesadaran membayar pajak $(\mathrm{z})$ & 0,390 & 0,024 & 0,05 \\
\hline
\end{tabular}

Sumber : data primer diolah, 2015

Berdasarkan tabel 9 diatas dapat dilihat bahwa nilai signifikannya $0,024<$ alpha o,05 sehingga dapat disimpulkan bahwa kesadaran membayar pajak berpengaruh terhadap kemauan membayar pajak, berarti $\mathrm{H}_{3}$ diterima pada penelitian ini. Kesadaran bahwa pajak merupakan bentuk partisipasi dalam menunjang pembangunan negara. Dengan menyadari hal ini, wajib pajak mau membayar pajak karena merasa tidak dirugikan dari pemungutan pajak yang dilakukan. Pajak disadari digunakan untuk pembangunan negara guna meningkatkan kesejahteraan warga negara (Vanessa dan Priyo 2009). 


\section{Uji Variabel intervening}

Untuk melihat kesadaran membayar pajak meintervening hubungan antara persepsi atas efektifitas sistem perpajakan dan pelayanan fiskus terhadap kemauan membayar pajak dapat dilihat pada gambar berikut ini :

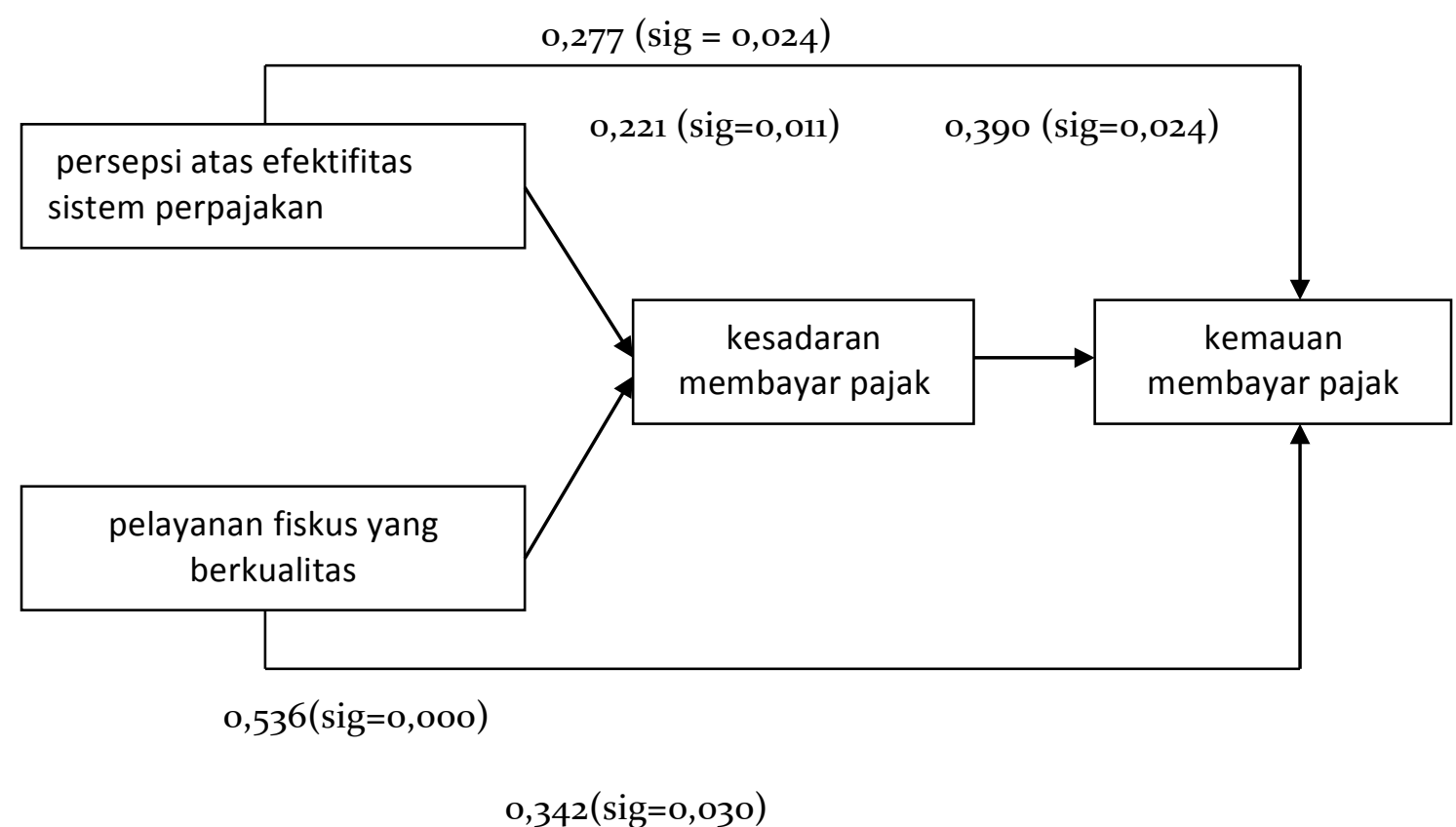

Gambar 2. Hasil Pengaruh Uji Variabel Intervening

Berdasarkan gambar dapat diuraikan hasil pengujian sebagai berikut :

Pengaruh persepsi atas efektifitas atas sistem perpajakan terhadap kemauan membayar pajak dengan kesadaran membayar pajak sebagai variabel intervening Berdasarkan gambar 2 diatas dapat dilihat pengaruh langsung dan tidak langsung persepsi atas efektifitas sistem perpajakan terhadap kemauan membayar pajak sebagai berikut :

Tabel 1o. Pengaruh Langsung Dan Tidak Langsung

Persepsi Atas Efektifitas Sistem Perpajakan Terhadap Kemauan Membayar Pajak

\begin{tabular}{|l|l|}
\hline $\begin{array}{l}\text { Pengaruh langsung persepsi atas efektifitas sistem } \\
\text { perpajakan ke kemauan membayar pajak (xı ke y) }\end{array}$ & $=0,277$ \\
\hline $\begin{array}{l}\text { Pengaruh tak langsung persepsi atas efektifitas } \\
\begin{array}{l}\text { sistem perpajakan ke kesadaran membayar pajak } \\
\text { ke kemauan membayar pajak (x ke z ke y) }\end{array}\end{array}$ & $=0,221 \mathrm{x} \quad 0,390$ \\
\hline
\end{tabular}

Berdasarkan hasil disimpulkan bahwa kesadaran membayar pajak tidak bisa meintervening hubungan antara persepsi atas efektifitas sistem perpajakan terhadap kemauan membayar pajak, disebabkan karena pada persamaan secara tidak langsung nilai koefisien regresinya sebesar o,086 lebih kecil dibandingkan hubungan secara langsung sebesar 0,277 meskipun semuanya dalam keadaan signifikan.

Hal ini juga mengindikasikan bahwa meskipun wajib pajak memiliki penghasilan, mengetahui hak dan kewajibannya dalam perpajakan, serta mengetahui sanksi pajak namun kebanyakan wajib pajak tersebut mendaftarkan diri untuk memperoleh NPWP disebabkan kebutuhan mereka akan NPWP itu sendiri, bukan karena kesadaran untuk 
membayar pajak sehingga kesadaran membayar pajak tidak bisa digunakan sebagai perantara untuk mempengaruhi persepsi atas efektifitas sistem perpajakan.

\section{Pengaruh pelayanan fiskus terhadap kemauan membayar pajak dengan kesadaran membayar pajak sebagai variabel intervening}

Berdasarkan gambar 2 diatas dapat dilihat pengaruh langsung dan tidak langsung pelayanan fiskus terhadap kemauan membayar pajak sebagai berikut :

Tabel 1o. Pengaruh Langsung dan Tidak Langsung Pelayanan Fiskus terhadap Kemauan Membayar Pajak

\begin{tabular}{|l|l|}
\hline Pelayanan fiskus ke kemauan membayar pajak & $=0,342$ \\
\hline $\begin{array}{l}\text { Pengaruh tak langsung Pelayanan fiskus ke } \\
\text { kesadaran membayar pajak ke kemauan } \\
\text { membayar pajak }\end{array}$ & $\begin{array}{l}=0,536 \times 0,390 \\
=0,209\end{array}$ \\
\hline
\end{tabular}

Berdasarkan hasil disimpulkan bahwa kesadaran membayar pajak tidak bisa meintervening hubungan antara pelayanan fikus terhadap kemauan membayar pajak, disebabkan karena pada persamaan secara tidak langsung nilai koefisien regresinya sebesar o,209 lebih kecil dibandingkan hubungan secara langsung sebesar 0,342 meskipun semuanya dalam keadaan signifikan.

Hal ini juga mengindikasikan bahwa meskipun pelayanan yang diberikan petugas wajib pajak baik, namun kebanyakan wajib pajak bukan lagi mempertimbangkan pelayanan yang diberikan kantor pajak dalam kesadarannya membayar pajak karena pelayanan yang baik memang harus diberikan oleh setiap kantor pajak, sehingga pelayanan fiskus tidak mampu menjadi perantara yang lebih baik secara tidak langsung untuk meningkatkan pengaruh pelayanan fiskus terhadap kemauan membayar pajak, disebabkan hasil yang diperoleh lebih baik pelayanan fiskus mempengaruhi kemauan membayar pajak secara langsung.

\section{SIMPULAN}

Dari hasil pengujian hipotesis yang telah dilakukan maka dapat disimpulkan sebagai berikut:

1. Persepsi atas efektifitas sistem perpajakan berpengaruh terhadap kesadaran membayar pajak

2. Pelayanan fiskus berpengaruh terhadap kesadaran membayar pajak

3. Kesadaran membayar pajak berpengaruh terhadap kemauan membayar pajak.

4. Kesadaran membayar pajak tidak bisa meintervening hubungan antara pengetahuan dan pemahaman akan peraturan perpajakan dan pelayanan fikus terhadap kemauan membayar pajak, disebabkan karena pada persamaan secara tidak langsung nilai koefisien regresinya lebih kecil dibandingkan hubungan secara langsung meskipun semuanya dalam keadaan signifikan

\section{PUSTAKA ACUAN}

Chatarina. 2004. Analisis terhadap Faktor-Faktor yang Mempengaruhi Kesadaran Wajib Pajak dalam Membayar Pajak. Skripsi. Fakultas Ekonomi Universitas Gajah Mada.

Ghozali, Imam 2013. Aplikasi Analisis Multivariate Dengan Program IBM SPSS21 Update PLS Regresi. Edisi 7.Semarang: Badan Penerbit Universitas Diponegoro. 
Judisseno, Rimsky. K. 2005. Pajak dan Strategi Bisnis Suatu Tinjauan tentang Kepastian Hukum dan Penerapan Akuntansi di Indonesia Edisi Revisi. Jakarta: Gramedia Pustaka Utama.

Nugroho, Rahman adi dan Zulaikha. 2012. Faktor-Faktor Yang Mempengaruhi Kemauan Untuk Membayar Pajak Dengan Kesadaran Membayar Pajak Sebagai Variabel Intervening (Studi Kasus Wajib Pajak Orang Pribadi Yang Melakukan Pekerjaan Bebas Yang Terdaftar Di KPP Pratama Semarang Tengah Satu).diponegoro journal of accounting Volume 1, Nomor 2, Tahun 2012, Halaman 1-11. Semarang.

Permadi Tedi, Azwir Nasir dan Yuneita Anisma. 2013. Studi kemauan membayar pajak pada wajib pajak orang pribadi yang melakukan pekerjaan bebas (Kasus Pada KPP Pratama Tampan Pekanbaru).Jurnal Ekonomi Volume 21, Nomor 2 Juni 2013, Halaman 1-18. Pekanbaru.

Purwono, Herry 2010. Dasar-Dasar Perpajakan \& Akuntansi Pajak. Jakarta: Erlangga.

Sekaran, Uma. 2011. Metodologi Penelitian Untuk Bisnis. Buku II.Edisi 4. Jakarta: Salemba Empat.

Sugiyono. 2003. Metode Penelitian Bisnis. Cetakan Kelima. Bandung : Alfabeta.

Suryadi.20o6. Model Hubungan Kausal Kesadaran, Pelayanan, Kepatuhan Wajib Pajak Dan Pengaruhnya Terhadap Kinerja Penerimaan Pajak: Suatu Survey Diwilayah Jatim. Jurnal Keuangan Publik. Vol.4 No.1: 105-121.Jawa Timur.

Undang-Undang Nomor 28 Tahun 2007 tentang "Perubahan Ketiga Atas Undang-Undang Nomor 6 Tahun 1983 Tentang Ketentuan Umum Perpajakan.

Vanessa Tatiana, Priyo Hari. 2009. Dampak sunset policy terhadap faktor-faktor yang mempengaruhi kemauan membayar pajak.Makalah Simposium Nasional IndonesiaPerpajakan II. Madura.

Widayati dan Nurlis. 2010.Faktor-Faktor Yang Mempengaruhi Untuk Membayar Pajak Wajib Pajak Orang Pribadi Yang Melakukan Pekerjaan Bebas (Studi Kasus Pada KPP Pratama Gambir Tiga). Proceeding Simposium Nasional Akuntansi XII. Halaman 123. Purwokerto.

Yulianawati, Nila. 2011. faktor-faktor yang mempengaruhi kemauan membayar pajak The Factors That Influence The Willingness To Pay The Tax. Jurnal Dinamika Keuangan dan Perbankan, Nopember 2011, Hal: 126 - 142 Vol. 3, No. 1 ISSN :1979-4878. 